\title{
DIRECT COERCION IN PSYCHIATRICS - INTERPRETATION OF LEGAL REGULATIONS AS AMENDED IN JUNE 2012
}

\begin{abstract}
The issues connected with direct coercion are of vital importance due to the fact that the application of coercive measures leads to restriction of personal freedom and limiting individual autonomy. It may even result in violating bodily integrity. Thus, it is an interference with the sphere of fundamental rights guaranteed to every human by the Constitution of the Republic of Poland.

The article includes an interpretation of the legal provisions concerning the application of direct coercion in psychiatrics. It comprises the changes which are in force as of June 2012. There is a comprehensive analysis of the meaning of the term "direct coercion", as well as a detailed study of the prerequisites of its application. The legal regulations related to the forms of exerting direct coercion are thoroughly scrutinized. Next, the analysis of current regulations is carried out in order to evaluate their coherence, clarity and accuracy. It is also examined whether the currently applicable legal regulations are sufficient and if the rights of persons against whom direct coercion is applied are appropriately secured and protected.
\end{abstract}

\section{Introduction}

Persons suffering from mental disorders constitute a specific category of patients due to their unstable frame of mind and, what is connected with it, unpredictability of behaviour. Their conduct is often uncontrolled mentally, which may cause danger both to them and the people in their immediate company. Mental disorders are frequently accompanied by aggression. Its consequence might be destroying various items being in close vicinity. Aggression could be directed both against other people and against the ill persons themselves and assume the form of self-aggression which may lead to health disturbances, physical injury and sometimes even to death. Family members and people in ill person's environment are most often exposed to 


\section{Joanna Huzarska}

such danger. It seems worth pointing out that during hospitalization other patients might become aggrieved. By and large, the members of the medical staff become injured.

Dangerous conduct of persons with mental disorders justifies taking action that is aimed at suppressing aggression and non-admission of inflicting damage. Taking the above into account, in order to safeguard legally protected rights, it is admissible to apply direct coercive measures. In such event a doctor takes action not only without the patient's consent but actually in spite of their objections and quite often against their active resistance.

M. Balicki (1999, p. 40) observes that the doctor's actions consisting in applying coercive measures, thus being against the patient's will, irrespective of their justifiable motives, are indeed restrictions of personal freedom, violating bodily integrity and individual autonomy. Therefore, such actions are equal to interference with the sphere of rights guaranteed to every individual by the Constitution.

According to T. Cysek and Ł. Korózs (1997, p. 95) direct coercion constitutes "the most drastic form of violating personal dignity of psychiatric patients". However, in certain situations, the application of coercion is necessary. In the opinion of the authors the treatment of some patients with mental disorders would be impossible without resorting to this measure.

The application of direct coercion towards persons with mental disordersis regulated by the ustawa z 19 sierpnia 1994 o ochronie zdrowia psychicznego (Dz. U. z 2011 Nr 231, poz. 1375 j.t.) - hereinafter referred to as "the Psychiatric Act" - and the relatively recent regulation of rozporządzenie Ministra Zdrowia z 28 czerwca 2012 r. w sprawie sposobu stosowania i dokumentowania zastosowania przymusu bezpośredniego oraz dokonywania oceny zasadności jego zastosowania (Dz. U. z 2012 r., poz. 740) - hereinafter referred to as "regulation concerning direct coercion of 2012". This regulation has replaced the former regulation of rozporzadzenie Ministra Zdrowia i Opieki Społecznej z 23 sierpnia 1995 r. w sprawie sposobu stosowania przymusu bezpośredniego (Dz. U. z 1995 Nr 103, poz. 514).

It seems worth emphasizing that the above mentioned provisions must be interpreted very restrictively since they allow for the possibility of violating important personal rights and open the door for posing a threat to personal dignity.

Direct coercion may be applied towards persons with mental disorders. The Psychiatric Act provides in art. 3 item 1 that these persons include:

- mentally ill persons (persons displaying psychotic dysfunctions),

- mentally handicapped, and 
Direct Coercion in Psychiatrics - Interpretation of Legal Regulations...

- persons who display other disturbances of mental activities which are, according to the medical knowledge, included to mental disorders and who require medical service or other forms of assistance and care indispensable to exist in family and society.

It needs to be stressed here that the legislator has precisely defined application of direct coercion by pointing to the forms in which it may be performed. Pursuant to art 3 item 6 of the Psychiatric Act one should comprehend the term "direct coercion" as:

- holding up,

- compulsory application of medicines,

- immobilization,

- isolation.

In addition, each of these measures contains a separate definition.

1. holding up - temporary, short-term immobilization of a person with the use of physical force;

2. compulsory application of medicines - temporary or planned in the course of medical treatment implementation of medicines to the organism of a person without their consent;

3. immobilization - incapacitating a person with the use of strips, handles, sheets, straitjackets or other technical devices;

4. isolation - allocating a person separately, in a confined and appropriately adapted premises.

It seems worth noticing that the definition of direct coercion was introduced to the Psychiatric Act as recently as on 11 February 2011. Previously, an identical provision was included in art 3-6 of the repealed regulation of 1995 concerning direct coercion. Undoubtedly, adopting such a definition in the Act was a timely legislative measure as such important issues should be regulated by a legal document equal in rank to an Act and not by a minor document.

It must be noticed that until the effective date of the current regulation concerning direct coercion, i.e. until June 2012, the definition of direct coercion could be found in both the binding legal documents, i.e. in the regulation and in the Act. The regulation concerning direct coercion of 2012 does not cite this definition, however. The legislator has justifiably assumed that since it is included in the Act, there is no point in reiterating it in the document of minor rank.

Moving on to the analysis of the term "direct coercion", it seems necessary to carry out a linguistic interpretation.

According to the dictionary of the Polish language, coercion means "duress, pressure exerted on someone, circumstances forcing someone to act 


\section{Joanna Huzarska}

against their will”. (Szymczak, 1979, p. 1048). Physical constraint is defined in the dictionary as "using force towards somebody, compelling somebody to something by using physical force". (Szymczak, 1979, p. 1048).

The term "direct" means "not having intermediary links, concerning somebody or something directly" (Szymczak, 1979, p. 148). "Directly" should be understood as:

1. without any intermediary, personally, straightforwardly..."

2. "in spatial terms: very close, right alongside; without any physical barrier..."

3. "at the moment following an event or precedent to an event..." (Szymczak, 1979, p. 148).

However, there is no definition of the term "direct coercion" as a whole.

Taking into account the above definitions, it appears that direct coercion towards a person with mental disorders might be interpreted as compelling them by using force to act in a certain way, e.g. abstain from aggression; exerting pressure for this purpose (without using physical force); making somebody behave against their will. Such behaviour is acceptable at the moment following undesirable behaviour of the patient or at the moment precedent to dangerous, violent behaviour. Two elements deserve being highlighted:

- firstly - immediate character, which requires acting at the moment that "immediately follows" aggressive behaviour, or "immediately precedes" dangerous behaviour, and

- secondly - compelling character, which involves acting against the patient's will, also by the use of force.

\section{Forms of direct coercion}

The legislator has determined which coercive measures may be applied and what they should consist in. It seems worth carrying out a thorough interpretation of the terms that appear in the regulations and considering whether the wording is precise enough and does not cause any doubt.

\subsection{Holding up}

According to art. 3 item 6a of the Psychiatric Act, holding up means a temporary, short-term immobilisation of a person with the use of physical force.

In accordance with the dictionary of the Polish language the expression "hold up" means: 
Direct Coercion in Psychiatrics - Interpretation of Legal Regulations...

- "to hold and not allow to move, leave, escape; detain for a short time; withhold (...)

- keep in a particular position, not allow to fall down, move away (...)

- hold and keep someone in a particular place for a certain time (...)". (Szymczak, 1979, p. 1062).

It appears that the term "holding up" itself is quite precise and consistent with its literal wording.

What does immobilization of the patient mean? How should this term be understood? According to the dictionary of the Polish language "immobilize" equals "make something or somebody stop moving; seize, halt". (Szymczak, 1981, p. 602).

The provision refers to a temporary, short-term immobilization. Therefore, it seems proper to deliberate on the meaning of these expressions.

"Short-term" means "applied circumstantially, in a particular situation, acceptable for some time; improvised, incidental, immediate". (Szymczak, 1978, p. 431). "Temporary" means: "lasting for a short time, transient, short-lived". (Szymczak, 1978, p. 431).

While carrying out a literal interpretation of the provision which defines a coercive measure as an act of holding up, it should be pointed out that this measure consists in immobilizing a person with mental disorders, thus maintaining them in a certain position, keeping them in a place, making them stand still. Such immobilization ought to be of short duration, last temporarily and be short-term, so it must be applied occasionally, as a measure acceptable at this very moment.

The legislator allows thereby to use physical force and here arises an issue: what does using force mean, and how large may be the applied force and what actions are acceptable? Apparently, this provision should be clarified so as the degree of using physical force could be determined as appropriate in the given circumstances to apply a coercive measure. One needs to emphasize the fact that violence must not be used. A. Milik notices that one cannot "blow strikes". According to this author it is accessible to "apply the elements of self-defence, including using the following grips in particular: incapacitating, transport, defensive and releasing ones." (Milik, 2007, p. 115).

\subsection{Compulsory application of medicines}

Pursuant to art 3 item $6 \mathrm{~b}$ of the Psychiatric Act compulsory application of medicines must be interpreted as a temporary or planned in the course of medical treatment implementation of medicines to the organism of a person without their consent. 


\section{Joanna Huzarska}

Apparently, this provision does not need clarification as it is clear and precise enough.

The coercive measure mentioned above consists in administering medications to the patient without their consent or even despite their objections. This may be understood as both one-off application of the medicine if such a necessity arises from the existing circumstances and administering the medicine within the frames of a pre-scheduled course of treatment. Coercion is necessary due to the fact that the patient refuses to take the medicine at their own free will. It is worth noticing that the provision mentions application of medicines. Consequently, it does not provide a basis for administering curatives which are not medicines. The legislator has not defined either what kind of medicine it must be. Therefore, not only is it a matter of administering tranquilizers (which will be administered occasionally), but also medicines causing various effects. Since the legislator uses the term "implementation of medicines to the organism of a person", it does not matter in what form it will happen: i.e. whether by oral application, intravenous drip or injection. What is worth highlighting here is the fact that the legislator does not allow for using physical force.

\subsection{Immobilization}

Pursuant to art. 3 item $6 \mathrm{c}$ of the Psychiatric Act immobilization consists in incapacitating a person with the use of strips, handles, sheets, straitwaistcoat or other technical devices.

According to the dictionary of the Polish language "immobilize" equals "render something immobile, make something or someone stop moving; seize, halt". (Szymczak, 1981, p. 602). "Incapacitate" means "render someone inert, powerless; deprive them of the freedom to move at ease". (Szymczak, 1979, p. 409).

Accomplishing a literal interpretation of this provision, one ought to acknowledge that direct coercion in the form of immobilization consists in depriving someone of their freedom to move at ease, halting them in place with the use of suitable objects.

For the purpose of incapacitating the patient the medical staff might apply, among other means, strips, handles or other technical devices. The legislator does not precise, however, what kind of strips they may be and what material they should be made of: are these leather strips, or made of other material. It is not clear either what is behind the term "handles": what they should be made of; what they must look like. The above mentioned provision also refers to a "technical device". Instantly, it must be 
pointed out that this is a very broad term and not precise enough. One can hardly guess what equipment was meant by the legislator. According to the dictionary of the Polish language a "device" is "a kind of mechanism or a set of elements, instrumental devices serving to perform certain actions (...)". (Szymczak, 1981, p. 619). Moreover, in accordance with the currently analyzed provision these should be "technical" devices. By the way, it seems worth adding that the wording "or other technical devices" means that the legislator recognizes strips, sheets or straitjackets as technical devices, which may be not fully comprehensible, particularly when one bears in mind the linguistic definition of this term. In addition, the legislator does not indicate that these must be devices similar to those previously mentioned in the provision. Thus, it may be assumed that these can be any technical devices.

To sum up the deliberations so far, one fact must be highlighted - while the term of immobilization itself is not questionable, the legislator's failure to provide a list of objects which may be applied to this purpose raises serious reservations.

It is definitely worth adding here that according to $\S 7$ of the regulation concerning direct coercion of 2012, direct coercion in the form of immobilization should be applied in one-person premises. In the event of the lack of such possibility direct coercion should be applied in the way which allows for separating the patient from other persons who are in the same room and provides respect of their dignity and intimacy. In particular, this refers to performing nursing procedures without the presence of other persons. The regulation concerning direct coercion of 1995 did not provide for such a requirement.

\subsection{Isolation}

The next coercive measure stipulated in the Psychiatric Act is isolation. Pursuant to art. 3 item $6 \mathrm{~d}$ of the document, isolation consists in allocating a person separately, in a confined and appropriately adapted premises.

$\S 8$ of the regulation concerning direct coercion of 2012 defines characteristics of such a place. It ought to be furnished in a way which protects a person with mental disorders from bodily injury and in a way equivalent in terms of sanitation and living conditions to other premises in a psychiatric hospital or unit of social institution. In addition, the isolation premises must be equipped with video surveillance installation enabling the medical staff to carry out constant supervision over the patient with mental disorders residing there and control their physical condition. It is worth emphasizing that the obligation to provide the premises with video surveillance instal- 


\section{Joanna Huzarska}

lation was introduced by the regulation concerning direct coercion of 2012 . Admittedly, thanks to this the regulator enhanced the guarantees of respecting patient's rights and increased the safety of isolated persons, thanks to their constant observation and the possibility to react immediately if such a need arises.

In accordance with the provisions of the Psychiatric Act, the coercive measures listed in art. 3 item 6 constitute a closed catalogue. It is unacceptable then to apply other measures except for those discussed above. There exists, however, a possibility to apply simultaneously a few of the coercive measures. Apparently, such a solution may be justifiable and in practice, together with holding up, immobilizing or isolation, compulsory application of tranquilizing medicines often takes place.

\section{Premises of applying direct coercion}

Apart from specifying coercive measures, the legislator thoroughly described the premises of their application. Pursuant to art 18 p. 1 of the Psychiatric Act, direct coercion towards persons with mental disorders may be exerted only when these persons:

1. commit attempts against their own life or health, or

2. commit attempts against other person's life or health, or

3. commit a crime against public safety, or

4. violently destroy or damage objects in their environment, or

5. gravely disturb or obstruct functioning of medical entity providing health services pertaining to mental care or a unit of social welfare institution.

Moreover, there is a possibility to apply direct coercion when the provision of the Psychiatric Act permits that. This encompasses the following situations:

A. conducting a compulsory psychiatric examination or transporting a person to a mental hospital for this purpose if their behaviour indicates that due to mental disorders they may pose an immediate threat to their own life or other persons' lives and health, or they are unable to cater for their own basic necessities (art. 21 p. 1 and 3 of the ustawa o ochronie zdrowia psychicznego (Dz. U. z 2011 Nr 231, poz. 1375 j.t.));

B. conducting a compulsory psychiatric examination for the purpose of issuing a medical statement justifying the need for treatment in a mental hospital (art. 30 p. 4 of the ustawa o ochronie zdrowia psychicznego (Dz. U. z 2011 Nr 231, poz. 1375 j.t.)); 
Direct Coercion in Psychiatrics - Interpretation of Legal Regulations...

C. if it is necessary in order to perform essential medical procedures that aim at removing the cause of admitting the patient to the mental hospital without their consent (art. 34 of the ustawa o ochronie zdrowia psychicznego (Dz. U. z 2011 Nr 231, poz. 1375 j.t.));

D. preventing a person admitted to hospital without their consent from leaving the place at will (art. 34 of the ustawa o ochronie zdrowia psychicznego (Dz. U. z 2011 Nr 231, poz. 1375 j.t.));

E. preventing a person, whose behaviour poses a threat to their own life or health or other persons' lives or health, from leaving a psychiatric institution at will (art. 49 p. 3 of the ustawa o ochronie zdrowia psychicznego (Dz. U. z 2011 Nr 231, poz. 1375 j.t.)).

It is a proper thing to pay attention to the fact that situations and purposes for which direct coercion may be applied towards a person with mental disorders are thoroughly defined by the legislator and cannot be extended by way of interpretation.

Let us now analyse the prerequisites that determine the admissibility of applying direct coercion.

1. A person with mental disorders commits an attempt against their own life or health or other persons' lives or health (art. 18 p. 1 item 1a of the ustawa o ochronie zdrowia psychicznego (Dz. U. z 2011 Nr 231, poz. 1375 j.t.)).

Apparently, this prerequisite has been precisely defined and does not need further in-depth interpretation. It seems worth pointing out that the expression "commit" has been used in a present tense. Thus, one should highlight the fact that it is admissible to apply a coercive measure only at the moment of dangerous behaviour but not in the situation preceding the attempt, or immediately following the attempt. Undesirable behaviour may consists in, among others, attempting to commit a suicide or self-mutilation or attacking another person, which might result in bodily injury or even death.

In such an event direct coercion is applied for the purpose of protecting the patient's life and health as well as for the purpose of protecting the lives and health of other persons. In hospital conditions most often it would be medical staff, but also other patients and visitors. Given that the protection of such vital rights as life and health is at stake, applying coercion in these circumstances should not raise any reservations.

2. A person with mental disorders commits a crime against public safety (art. 18 p. 1 item 1b of the ustawa o ochronie zdrowia psychicznego (Dz. U. z 2011 Nr 231, poz. 1375 j.t.)). 


\section{Joanna Huzarska}

According to M. Balicki (1999, p. 53) the above describes a situation when the patient's behaviour poses a threat to a bigger number of people or the property of considerable value, e.g. causing real danger of setting fire, triggering explosion or bringing about a disaster.

Here, coercion is applied in order to protect this person's or other persons' life and health as well as to protect substantial property.

3. A person with mental disorders violently destroys or damages objects in their environment (art. 18 p. 1 item 2 of the ustawa o ochronie zdrowia psychicznego (Dz. U. z 2011 Nr 231, poz. 1375 j.t.)).

According to the dictionary of the Polish language "destroy" is synonymous to: "annihilate, extinguish, demolish (...); cause exhaustion, decay, deterioration (...)" (Szymczak, 1979, p. 381); whereas "damage" is equivalent to "partially destroy, bring about a minor defect, spoil, impair, strain, derogate." (Szymczak, 1981, p. 629). In accordance with the literal wording of these expressions one may assume that the behaviour of the patient which consists in impairing or partially destroying objects justifies applying direct coercion towards them. Furthermore, the legislator stipulates that such behaviour must be violent, thus "impulsive, impetuous, quick-tempered, (...) turbulent, vehement; abrupt, rapid, quick." (Szymczak, 1978, p. 715).

The object of protection is tangible property which is located in the environment of the patient with mental disorders. It is necessary to notice that the provision in question does not precisely define:

- what kind of property it is,

- what is the value of the property,

- who is the owner of this property.

This means that destroying something abruptly, even a valueless item, gives grounds for applying a coercive measure. It does not matter either that the owner of this property is the destroyer himself. Such a structure of the provision appears to be incomprehensible. Even more so, given that from the property law stems the right of the owner to destroy the item (iusabutendi). Moreover, one can hardly accept the admissible and lawful possibility of using direct coercion to the aim of protecting a valueless item. Apparently, the current wording of the provision being interpreted may raise serious doubts, bearing in mind in particular the fact that applying a coercive measure always constitutes infringement of human rights, including the right for self-determination and may lead to violating the patient's dignity.

It seems proper to agree with K. Zgryzek (1996, p. 395) that the current wording of this provision results in the situation when the issue of lawfulness 
Direct Coercion in Psychiatrics - Interpretation of Legal Regulations...

of the application of direct coercion is dependent on the arbitrary assessment of the subject authorised to apply it.

In view of the above, it should be determined that this provision is derogatory. There are proper grounds for introducing a provision that determines the minimal value of the object as, for instance, considerable, major or substantial value. It should be also stipulated that these are objects which do not belong to the person destroying those objects.

4. A person with mental disorders gravely disturbs or obstructs functioning of medical entity providing health services pertaining to mental care or a unit of social welfare institution (art. 18 p. 1 item 3 of the ustawa o ochroniezdrowiapsychicznego (Dz. U. z 2011 Nr 231, poz. 1375 j.t.)).

What is worth emphasizing here is the fact that pursuant to the above provision applying direct coercion is not justified by any disturbance of functioning of medical entity but this disturbance must be aggravated, thus massive, as it appears. It refers likewise to the situation when functioning of the medical institution is actually obstructed.

J. Duda (2012, p. 196) remarks that the term "gravely", due to its vagueness, may give grounds for abusive behaviour of the medical staff towards the patients with mental disorders, since it might be understood and interpreted in various ways.

In the case mentioned above, the coercion is applied for the purpose of protecting other patients of the medical entity so that they can take advantage of the provided services.

As it appears, in practice the discussed provision will not be a frequent basis for applying direct coercion, since one can hardly imagine a behaviour which is oppressive and dangerous enough that it may result in a serious disturbances in the work or obstruction of functioning of, say, psychiatric hospital. However, should such situation occur, only two out of four coercive measures, i.e. holding up or compulsory application of medicines (art. 18 p. 6 of the ustawa o ochronie zdrowia psychicznego (Dz. U. z $2011 \mathrm{Nr} 231$, poz. 1375 j.t.)) may be used towards these patients.

To sum up the above discussion, one must point out that the prerequisites and purposes for which direct coercion towards a person with mental disorders can be applied are quite clearly determined by the legislator. An unacceptable practice then is applying a coercive measure for other purposes such as the inclination to punish a patient, or in order to discipline them, or for the convenience of the medical staff towards cumbersome or importunate patients (cf. Ciecierska, Gajdus, 1998, p. 69), or for the purpose of subordinating the patients to the personnel's will. 


\section{Joanna Huzarska}

It is worth emphasizing that the doctor, while deciding whether to apply a direct coercive measure, should always do their best to appropriately evaluate the circumstances, bearing in mind that the essential issue is ensuring safety of the patient towards whom coercion will be exerted, as well as securing other persons' safety. Protecting property, including the equipment of the institution, should be a matter of secondary importance. (Milik, 2007, p. 124).

\section{General principles of applying direct coercion}

While analysing the provisions that permit applying direct coercion, three general principles of its application ought to be listed:

1. It is the doctor who decides whether to use coercive measures. The doctor also determines the type of coercive measure which is to be applied and personally supervises performing the action (art 18 p. 2 of the ustawa o ochronie zdrowia psychicznego (Dz. U. z 2011 Nr 231, poz. 1375 j.t.)). In exceptional situations, if it is impossible to obtain an instant decision of the doctor, a nurse, who is to inform the doctor promptly, may decide as to the application of coercion.

2. Prior to applying direct coercion the patient, towards whom the coercive measure is to be applied, should be informed about it (art 18 p. 8 sent. 1 of the ustawa o ochronie zdrowia psychicznego (Dz. U. z $2011 \mathrm{Nr} 231$, poz. 1375 j.t.)).

M. Balicki (1999, p. 54) takes note of the fact that explanation of the reason and purpose of applying a coercive measure may result in the patient's consent for suggested procedures without exerting coercion. Alternatively, it may contribute to mitigation of their resistance.Besides, every individual has the right to be informed what procedures and why they will be implemented towards them.

Owing to various circumstances and reasons, it is lawful to concurrently inform the patient and commence application of coercive measure. (Paprzycki, 1996, p. 22).

3. While choosing a coercive measure, one should opt for the measure which is possibly the least severe for the patient (art. 18 p. 8 sent. 2 of the ustawa o ochronie zdrowia psychicznego (Dz. U. z 2011 Nr 231, poz. 1375 j.t.)).

4. Upon applying coercion one ought to exercise particular caution and care for the person's well-being (art. 18 p. 8 sent. 2 of the ustawa o ochronie zdrowia psychicznego (Dz. U. z 2011 Nr 231, poz. 1375 j.t.)). 
Direct Coercion in Psychiatrics - Interpretation of Legal Regulations...

5. Direct coercion may last only until the reason for its implementation ceases to exist ( $\S 3$ of the rozporządzenie $\mathrm{w}$ sprawie sposobu stosowania i dokumentowania zastosowania przymusu bezpośredniego oraz dokonywania oceny zasadności jego zastosowania (Dz. U z 2012 r., poz. 740)).

Accordingly, the applied coercive measure ought to be withdrawn if the reason for its application ceases to exist. It must be emphasized, however, that such an obligation stems from the regulation but not from the Act, which is a defective solution. It ought to be provided for by a provision of statutory rank.

6. A system of monitoring and supervising the applied coercive measures is provided for by the law.

7. The evaluation of justification of application of direct coercion needs to be done (art. 18 p. 10 of the ustawa o ochronie zdrowia psychicznego (Dz. U. z 2011 Nr 231, poz. 1375 j.t.)).

8. The application of direct coercion must be adequately documented (art. 18 p. 2 sent. 3 of the ustawa o ochronie zdrowia psychicznego (Dz. U. z 2011 Nr 231, poz. 1375 j.t.)).

Pursuant to $\S 12$ of the regulation concerning direct coercion of 2012, each application of whatever coercive measure is to be registered in individual and collective medical documentation. Should direct coercion be applied in psychiatric hospital, the following things must be noted in the case history: the measure which was applied, the reasons for its application (including the justification of choice), the duration of its application and the reasons for prolongation of the procedure, information about a notice concerning application of coercion given to the patient ( $\S 13$ of the rozporządzenie $\mathrm{w}$ sprawie sposobu stosowania i dokumentowania zastosowania przymusu bezpośredniego oraz dokonywania oceny zasadności jego zastosowania (Dz. U z 2012 r., poz. 740)).

It seems worth pointing to some amendments that regard the application of coercive measures which have been introduced by the regulation concerning coercive measures of 2012.

1. There has been introduced a requirement to obtain another psychiatrist's opinion if the doctor, having prolonged the application of coercion in the form of immobilization or isolation twice, wants to prolong the procedure again.

2. There has been introduced an obligation to inform the ward head about any case of applying direct coercion in the form of immobilization or isolation for more than 24 hours.

3. The duration of applying coercive measure in the form of immobilization or isolation in the unit of social institution has been reduced from 24 


\section{Joanna Huzarska}

to 8 hours. Any further prolongation of the application can exclusively take place in a hospital setting.

4. There has been introduced a requirement that direct coercion in the form of immobilization must be applied in a one-person premises.

5. There has been introduced a requirement for the isolation premises to be equipped with video surveillance system. The principles of conducting surveillance have also been established.

6. It has been determined in more detail how application of direct coercion must be documented.

7. According to new regulations direct coercion may be exerted only by persons appropriately instructed in this field (formerly, it could be done by appropriately instructed medical staff but also by other persons in their presence).

8. It has been described in detail what circumstances are to be taken into account while making judgement as to the justification of applying direct coercion.

\section{Practical implementation of the regulations concerning direct coercion}

Let us present the results of the report of the Supreme Chamber of Control dated 8 May 2012 on the control which was carried out regarding compliance with the provisions concerning application of direct coercion in Poland. (Nr ewid. 19/2012/P/11/093/KZD). The inspection was carried out in 18 hospitals, including 11 psychiatric hospitals, 7 psychiatric wards in general hospitals, located within 9 voivodeships.

As the result of the analysis of 153 case histories containing 199 sheets of "Register of Application of Immobilisation or Isolation" of the patients towards whom direct coercion was applied a number of irregularities have been found. These include:

- lack of record in the case history containing the description of medical examination which justifies administering the application of coercion (92 cases - 46.2\%) and the examination preceding the decision concerning the prolongation of its application for subsequent 6 -hour terms $(114$ cases $-57.3 \%)$;

- lack of the confirmation of the evaluation of the grounds for applying direct coercion carried out by the head of hospital (89 cases $-44.7 \%$ ); 
Direct Coercion in Psychiatrics - Interpretation of Legal Regulations...

- failure to register in patients' documents instances of short-term release from immobilisation every 4 hours, satisfying physiological needs, taking in meals and beverages (97 cases - 48.7\%).

In addition to the above, there have been found cases of:

- administering direct coercion for 24 hours immediately,

- failure to note down the date, time and reasons for prolongation of applying coercion,

- lack of confirmation that the hospital head has been notified of the applied coercion,

- the duration of placing a patient in safety has not been noted, the type of safety devices used has not been indicated, or the time of releasing the patient from safety devices has not been recorded.

\section{Conclusion}

To sum up the above discussion, it seems important to highlight that accurate interpretation of the provisions which regulate application of direct coercive measures is of great significance. It is worth stressing here that direct coercion is not subject to automatic control of the court. As it follows form the carried out inspections, in practice the provisions concerning the application of direct coercion are not always observed.

Finally, one must stress the fact that the legislator quite thoroughly specified the premises of applying direct coercion and defined the particular coercive measures. The principles of application of coercive measures have been established as well. Moreover, for the purpose of protecting the rights of the persons with mental disorders, there have been introduced some provisions aimed at reinforcement of the supervision over executing coercion. In spite of all these legislative measures, it must be acknowledged that not all provisions are clear enough and not all solutions are sufficient. This conclusion is additionally supported by alarming results of the carried out inspections that regard respecting patients' rights in connection with application of direct coercion.

R E F E R E N C E S

Balicki, M. (1999). Przymus w psychiatrii - regulacje i praktyka. Prawo i medycyna, $1,40$.

Ciecierska, A., D. Gajdus, (1998). Ochrona zdrowia psychicznego. Kontrola Państwowa, 1, 69. 


\section{Joanna Huzarska}

Cysek, T., Korózs Ł. (1997). Funkcjonowanie ustawy o ochronie zdrowia psychicznego. Monitor Prawniczy, 3, 95.

Duda, J. (2012). Komentarz do ustawy o ochronie zdrowia psychicznego. Warszawa: LexisNexis, 196.

(Ed.) Szymczak, M. (1978). Stownik jezyka polskiego, Volume I. Warszawa: PWN, 431.

(Ed.) Szymczak, M. (1979). Stownik języka polskiego, Volume II. Warszawa: PWN, $1048,1062$.

(Ed.) Szymczak, M. (1981). Stownik jezyka polskiego, Volume III. Warszawa: PWN, 602.

Informacja o wynikach kontroli NIK Przestrzegania praw pacjenta w lecznictwie psychiatrycznym z dnia 8 maja 2012 r.; Nr ewid. 19/2012/P/11/093/KZD; http://www.nik.gov.pl/plik/id,3950,vp,5024.pdf, accessed 25 November, 2012.

Milik, A. (2007). Przymus bezpośredni w psychiatrii w świetle obowiązujących przepisów. Prawo i medycyna, 2, 115.

Paprzycki, L. (1996). Ustawa o ochronie zdrowia psychicznego. Wprowadzenie. Kraków: Kantor Wydawniczy Zakamycze, 22.

Rozporządzenie Ministra Zdrowia i Opieki Społecznej z 23 sierpnia 1995 r. w sprawie sposobu stosowania przymusu bezpośredniego (Dz. U. z 1995 r. Nr. 103, poz. 514).

Rozporządzenie Ministra Zdrowia z 28 czerwca 2012 r. w sprawie sposobu stosowania i dokumentowania zastosowania przymusu bezpośredniego oraz dokonywania oceny zasadności jego zastosowania (Dz. U z 2012 r., poz. 740).

Ustawa z 19 sierpnia 1994 o ochronie zdrowia psychicznego, (Dz. U. z 2011 Nr 231, poz. 1375 j.t.).

Zgryzek, K. (1996). Przestanki stosowania przymusu bezpośredniego wobec osób $z$ zaburzeniami psychicznymi w trybie ustawy o ochronie zdrowia psychicznego. Katowice: Wydawnictwo Uniwersytetu Śląskiego, 395. 